\title{
TWO LARVAL CHARACTERS TO SEPARATE COPITARSIA INCOMMODA (WALKER) FROM C. DECOLORA (GUENÉE ) (LEPIDOPTERA: NOCTUIDAE)
}

\section{DOS CARACTERES LARVALES PARA SEPARAR A COPITARSIA INCOMMODA (WALKER) DE C. DECOLORA (GUENÉE) (LEPIDOPTERA: NOCTUIDAE)}

\author{
Andrés O. Angulo ${ }^{1} \&$ Tania S. Olivares ${ }^{2}$ \\ ${ }^{1}$ Casilla 160-C. Departamento de Zoología. Facultad de Ciencias Naturales y Oceanográficas. \\ Universidad de Concepción.E-mail: aangulo@udec.cl \\ ${ }^{2}$ Casilla 4040 correo 3. Concepción. Chile.
}

\begin{abstract}
RESUMEN
Se entregan caracteres taxonómicos de las larvas de Copitarsia decolora (Guenée) y C. incommoda (Walker), que permite la diferenciación entre ellas. Ambas especies tiene importancia cuarentenaria para los exportadores en Chile.

Palabras Claves: Copitarsia, Cucullinae, larvas, taxonomía.
\end{abstract}

\section{ABSTRACT}

Diagnostic larval features of Copitarsia Hampson, C. decolora (Guenée) and C. incommoda (Walker) involving spinneret and pinnaculae are given. Both species are importance quarantine pest for chilean exporters.

Keywords: Copitarsia, Cucullinae, larvae, taxonomy.

Copitarsia Hampson, 1906, consists of twenty-one species distributed from México to the Patagonia (Angulo \& Olivares 2003); some species are severe pests in agriculture and quarantine procedures. Copitarsia decolora (Guenée), Copitarsia incommoda (Walker) are two of these species injuring the aspa-ragus. This suggests the importance of the differential features given here.

Larvae were brought from Mexico and Colombia following careful examination the exoeskeleton was prepared and submitted to quetotaxy analysis.

Larval features of Copitarsia are four pairs of abdominal prolegs and one anal pair; adfrontal suture do not reach the occipital sein; smooth epidermis without ornamental structures; the two dorsal thoracic pinnaculae with a ligth area contrastig with the background colour.

\section{FEATURES OF PINNACULAE AND SPINNERET}

C. incommoda: The two dorsal thoracic pinnaculae are separed (at least twice their lenght) and are sorrounded by a dark pigmentary area with "sand clock" form (Fig. 3); spinneret: border of one lip with ca. 8 regular spines (Fig. 1). 
C. decolora: The two dorsal thoracic pinnaculae are aside and sorrounded by a dark circular pigmentary area (Fig.4); spinneret: border of one lip with many irregular spines (more than 8) (Fig.2).
Remarks: No differences were found in pupal features of both species; but it may be possible to find some of them under the ultrastructural scope. The pigmentary exoskeleton of larvae usually varies from dark to green light colour.
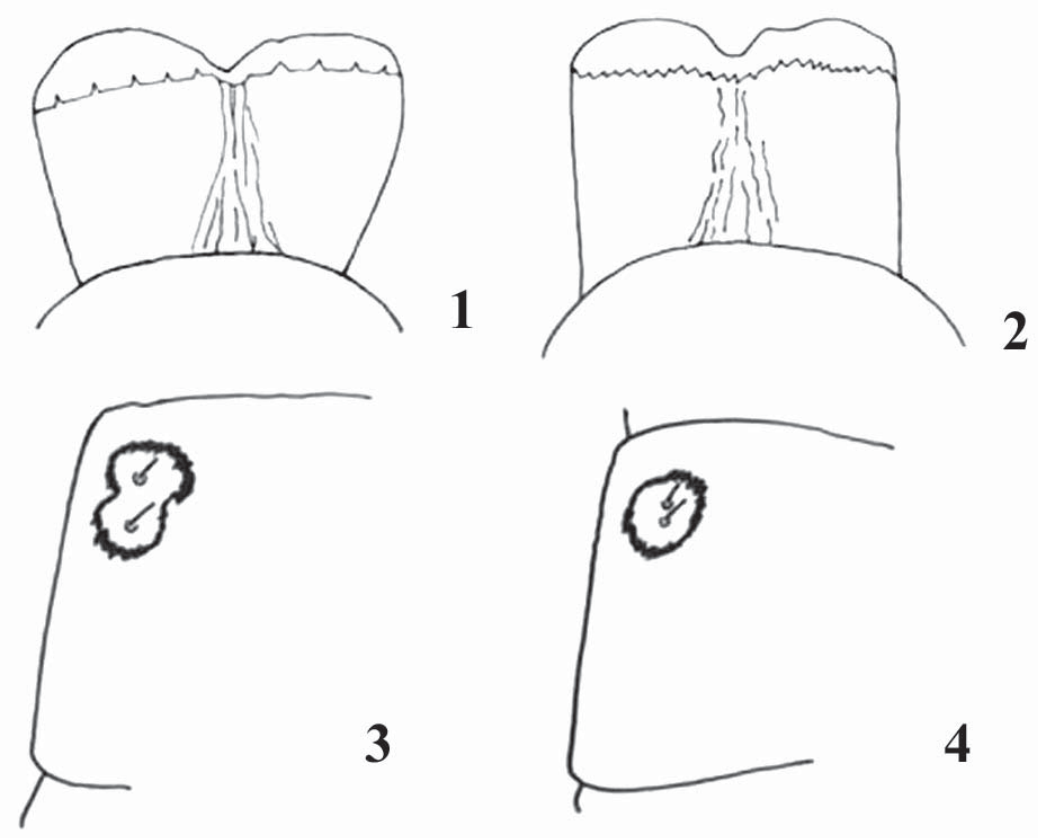
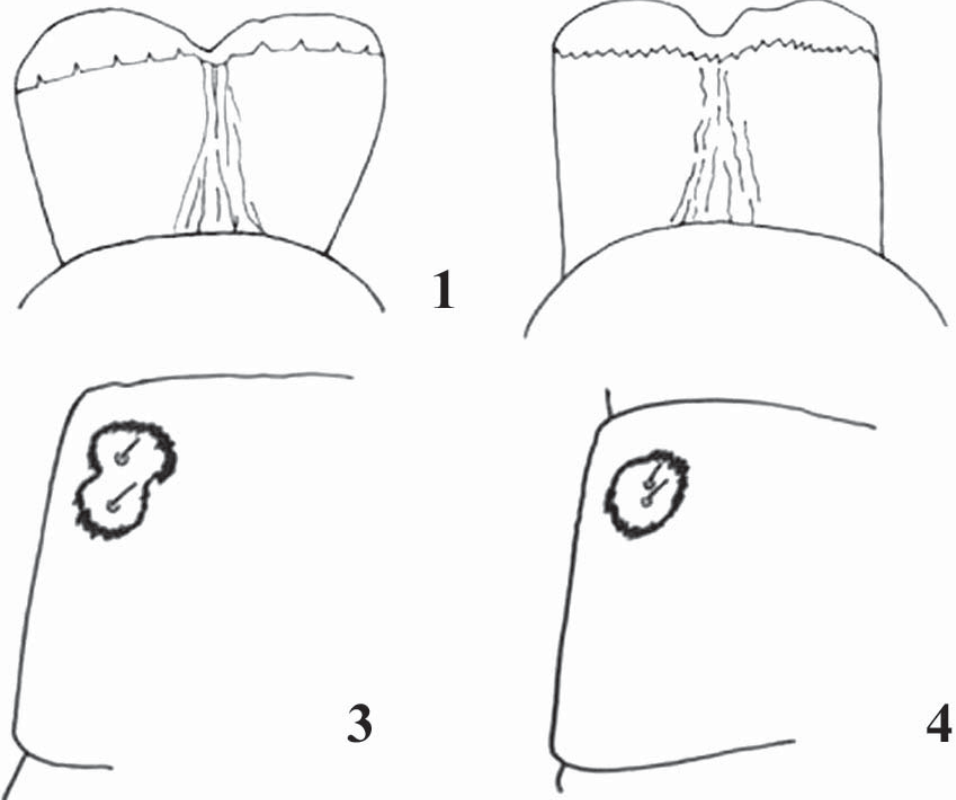

Figuras 1-4. Copitarsia decolora (Guenée): 1. spinneret 3. pinnaculae in $1^{\text {st }}-2^{\text {st }}$ abdominal segment. Copitarsia incommoda (Walker): 2. spinneret 4. pinnaculae in $1^{\text {st }}-2^{\text {st }}$ abdominal segment.

\section{ACKNOWLEDGMENTS}

Thanks to Dr. Néstor Bautista and Mr. Roberto Flores for the larval and pupal material from México. Also we thank the Project No 203.113.060-1.0 from Research Direction of the University of Concepción. Concepción, Chile.

\section{BIBLIOGRAPHY}

Angulo, A.O. \& T.S. Olivares. 2003. Taxonomic updated of the species of Copitarsia Hampson, 1906 (Lepidoptera: Noctuidae: Cucullinae). Gayana 67(1):3338 .

Fecha de recepción: 05/10/04

Fecha de aceptación: 17/08/05 